Contributors: MMR had the original idea of the study, conducted the study, analysed and interpreted the data, and prepared the manuscript; he will act as guarantor for the paper. SHV, MAW, GJF, AHB, and JOA assisted with the interpretation and presentation of the paper. Fahmida Tofail supervised data collection, and Mohammed Ali helped with computer programming. Charles Stephensen, Grace Marquis, Nalini Sathiakumar, and Douglas Passaro helped in editing and reviewing the manuscript Funding: Thrasher Research Fund.

Competing interests: None declared.

1 Sommer A, Tarwotjo I, Djunaedi E, West KP Jr, Loeden AA, Tilden R, et al. Impact of vitamin A supplementation on childhood mortality. A randomized controlled community trial. Lancet 1986;1:1169-73.

2 Rahmathullah L, Underwood BA, Thulasiraj RD, Milton RC, Ramaswamy $\mathrm{K}$, Rahmathullah R, et al. Reduced mortality among children in southern India receiving a small weekly dose of vitamin A. N Engl J Med 1990;323: 929-35.

3 Fawzi WW, Chalmers TC, Herrera MG, Mosteller F. Vitamin A supplementation and child mortality. A meta-analysis. JAMA 1993;269: 898-903.

4 West KP Jr, Pokhrel RP, Katz J, LeClerq SC, Khatry SK, Shrestha SR, et al. Efficacy of vitamin A in reducing preschool child mortality in Nepal. Lancet 1991;338:67-71.

5 Lie C, Ying C, Wang EL, Brun T, Geissler C. Impact of large-dose vitamin A supplementation on childhood diarrhoea, respiratory disease and growth. Eur J Clin Nutr 1993;47:88-96.

6 Ghana VAST Study Team. Vitamin A supplementation in northern Ghana: effects on clinic attendances, hospital admissions, and child mortality. Lancet 1993;342:7-12.

7 Bhandari N, Bhan MK, Sazawal S. Impact of massive dose of vitamin A given to preschool children with acute diarrhoea on subsequent respiratory and diarrhoeal morbidity. BMJ 1994;309:1404-7.

8 Barreto ML, Santos LM, Assis AM, Araujo MP, Farenzena GG, Santos PA, et al. Effect of vitamin A supplementation on diarrhoea and acute lowerrespiratory-tract infections in young children in Brazil. Lancet 1994:344:228-31.

9 Rahmathullah L, Underwood BA, Thulasiraj RD, Milton RC. Diarrhoea, respiratory infections, and growth are not affected by a weekly low-dose vitamin A supplement: a masked, controlled field trial in children in southern India. Am J Clin Nutr 1991;54:568-77.

10 Abdeljaber MH, Monto AS, Tilden RL, Schork MA, Tarwotjo I. The impact of vitamin A supplementation on morbidity: a randomized community intervention trial. Am J Public Health 1991;81:1654-6.

11 Ramakrishnan U, Latham MC, Abel R, Frongillo EA Jr. Vitamin A supplementation and morbidity among preschool children in south India. Am J Clin Nutr 1995;61:1295-303.

12 Dibley MJ, Sadjimin T, Kjolhede CL, Moulton LH. Vitamin A supplementation fails to reduce incidence of acute respiratory illness and diarrhea in preschool-age Indonesian children. J Nutr 1996;126:434-42.
13 Christian P, West KP Jr. Interactions between zinc and vitamin A: an update. Am J Clin Nutr 1998;68:435-41S.

14 Smith JC Jr, McDaniel EG, Fan FF, Halsted JA. Zinc: a trace element essential in vitamin A metabolism. Science 1973;181:954-5.

15 Shingwekar AG, Mohanram M, Reddy V. Effect of zinc supplementation on plasma levels of vitamin $\mathrm{A}$ and retinol-binding protein in malnourished children. Clin Chim Acta 1979;93:97-100.

16 Rahman MM, Wahed MA, Fuchs GJ, Baqui AH, Alvarez JO. Synergistic effect of zinc and vitamin A on the biochemical indexes of vitamin A nutrition in children. Am J Clin Nutr 2001 (in press).

17 Faruque AS, Mahalanabis D, Haque SS, Fuchs GJ, Habte D. Double-blind, randomized, controlled trial of zinc or vitamin A supplementation in young children with acute diarrhoea. Acta Paediatr 1999;88:154-60.

18 Sazawal S, Black RE, Bhan MK, Jalla S, Bhandari N, Sinha A, et al. Zinc supplementation reduces the incidence of persistent diarrhea and dysentery among low socioeconomic children in India. J Nutr 1996;126:44350 .

19 Sazawal S, Black RE, Bhan MK, Jalla S, Sinha A, Bhandari N. Efficacy of zinc supplementation in reducing the incidence and prevalence of acute diarrhea-a community-based, double-blind, controlled trial. Am J Clin Nutr 1997;66:413-8.

20 Stansfield SK, Pierre-Louis M, Lerebours G, Augustin A. Vitamin A supplementation and increased prevalence of childhood diarrhoea and acute respiratory infections. Lancet 1993;342:578-82.

21 Stephensen CB, Franchi LM, Hernandez H, Campos M, Gilman RH, Alvarez JO. Adverse effects of high-dose vitamin A supplements in children hospitalized with pneumonia. Pediatrics 1998;101:E3.

22 Sempertegui F, Estrella B, Camaniero V, Betancourt V, Izurieta R, Ortiz $\mathrm{W}$, et al. The beneficial effects of weekly low-dose vitamin A supplementation on acute lower respiratory infections and diarrhea in Ecuadorian children. Pediatrics 1999;104:e1.

23 Ruel MT, Rivera JA, Santizo MC, Lonnerdal B, Brown KH. Impact of zinc supplementation on morbidity from diarrhea and respiratory infections among rural Guatemalan children. Pediatrics 1997;99:808-13.

24 Sugarman B. Zinc and infection. Rev Infect Dis 1983;5:137-47.

25 Stankova L, Drach GW, Hicks T, Zukoski CF, Chvapil M. Regulation of some functions of granulocytes by zinc of the prostatic fluid and prostate tissue. J Lab Clin Med 1976;88:640-8.

26 Mustafa MG, Cross CE, Munn RJ, Hardie JA. Effects of divalent metal ions on alveolar macrophage membrane adenosine triphosphatase activity. J Lab Clin Med 1971;77:563-71.

27 Schlesinger L, Arevalo M, Arredondo S, Lonnerdal B, Stekel A. Zinc supplementation impairs monocyte function. Acta Paediatr 1993;82:734-8.

28 Doherty CP, Sarkar MA, Shakur MS, Ling SC, Elton RA, Cutting WA. Zinc and rehabilitation from severe protein-energy malnutrition: higher-dose regimens are associated with increased mortality. Am J Clin Nutr $1998 ; 68: 742-8$.

(Accepted 3 May 2001)

\title{
Failure to report ethical approval in child health research: review of published papers
}

Agency for

Healthcare

Research and

Quality, Rockville,

MD 20852, USA

Howard Bauchner

child and adolescen

health scholar in

residence

Division of General

Pediatrics,

Department of

Pediatrics, Boston

University School of

Medicine, Boston,

MA 02118, USA

Joshua Sharfstein

fellow

Correspondence to:

H Bauchner

hbauchne@ahrq.gov

BMJ 2001;323:318-9
More than 500 journals have adopted the uniform requirements of the International Committee of Medical Journal Editors, which stipulate that authors should "indicate whether the procedures followed were in accordance with the ethical standards of the responsible committee on human experimentation." ${ }^{1}$ One major purpose of institutional review is to ensure that informed consent is obtained when possible. We investigated how often research publications about child health report ethics committee approval or informed consent.

\section{Methods and results}

We reviewed all research reports related to child health (involving patients $<18$ years, pregnant women, or clinicians providing care to children) published in 1999 in five American journals (JAMA,
New England Journal of Medicine, Pediatrics, Journal of Pediatrics, Archives of Pediatrics and Adolescent Medicine). Each report was reviewed independently by two research assistants for any statement about informed consent or ethics committee approval; if either statement was present, the report was categorised as having ethical approval. An article that referred to another publication for more details was not reviewed. This approach has been used previously. ${ }^{2}$ All five journals require studies with human participants to report ethical approval. Reports not describing approval were reviewed again by an investigator to ensure that errors in categorisation of the studies had not been made. Studies were also categorised according to design. The ethics committee at Boston University School of Medicine judged that this project did not represent research involving human subjects and did not require review. 
Reporting of ethical approval articles on child health in five American journals in 1999. Values are numbers (percentages)

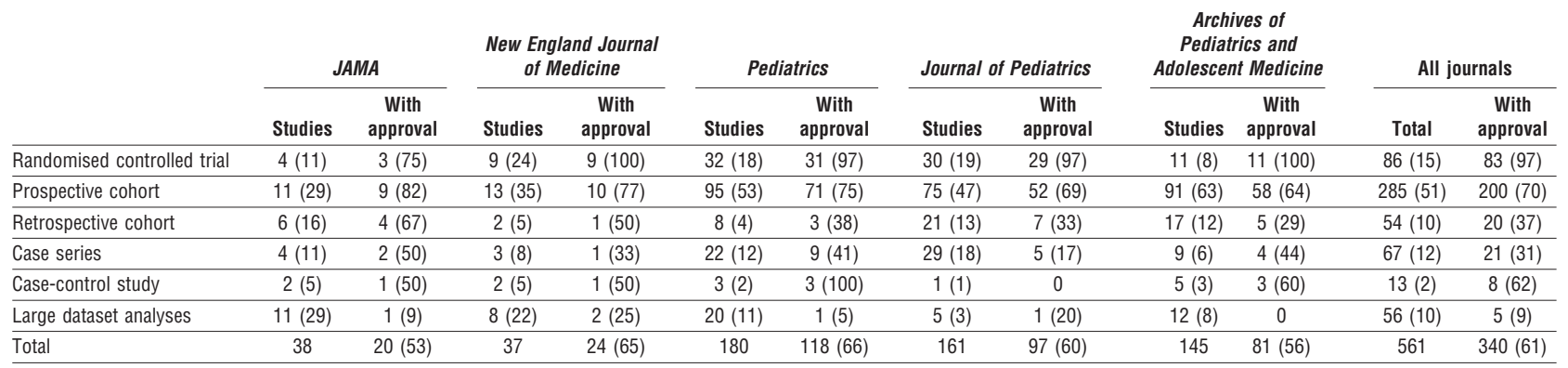

The journals contained 561 research reports related to child health. Overall, 340 (61\%, range 53-66\%) publications had ethical approval (table). The proportion of studies reporting ethical approval was dependent on the study type.

\section{Comment}

Despite increasing concern about the protection of human subjects, $40 \%$ of papers did not report ethical approval. These findings are particularly unexpected, since all five journals explicitly ask authors to document approval-24\% of medical journals do not include such instructions. ${ }^{3}$ Although we reviewed only American publications, we are not aware of data showing that papers published in non-American journals report ethical approval more frequently.

There are three possible explanations for the low proportion of papers that do not report ethical approval. Approval may have been obtained, but not reported-this situation is likely to be rare and is inconsistent with instructions to authors. Random non-reporting cannot explain differences between study types.

Investigators may have failed to obtain and report ethical approval because of confusion about the requirements. Nearly all investigators obtained approval for randomised controlled trials, a study design widely recognised to require safeguards. However, researchers may not realise that ethics committee approval and informed consent may be required for studies that do not enrol participants or that use large datasets. Some of the prospective cohort studies without approval could have been considered to be quality improvement projects (audits), and there is no consensus about when such projects become research. The Institute of Medicine recently said that the project represents research and approval is necessary if the investigator intends to publish the findings. ${ }^{4}$ Some researchers may have deliberately disregarded ethical approval standards and laws. Such occurrences are likely to be rare, but they are not inconceivable.

Unless we enhance our system of safeguards, an unethical study could be published. While the primary responsibility for assuring ethical conduct of research rests with investigators, peer review journals should be more active in protecting human subjects.

We have four recommendations to prevent unethical research being published. Just as every article has a list of authors, every research study should include a statement regarding human subjects. Articles should not refer to other publications for information regard- ing ethical approval. If the investigators believe that the research does not need to be reviewed by the ethics committee, the reason for exemption should be provided (however, we believe that investigators should not make such a decision). Investigators should document approval from the ethics committee and whether informed consent was obtained-as discussed previously, ${ }^{5}$ these are not synonymous.

Protecting participants in clinical research is, and must remain, one of the highest priorities of medicine. As the final conduit of most biomedical research, peer review journals can play a greater role in protecting human participants by ensuring that every report of clinical research contains a statement about the participants' protection.

The views expressed in this article are those of the authors and not necessarily of Agency for Healthcare Research and Quality or US Department of Health and Human Services. We thank Dr Helen Burstin and Dr John Eisenberg for their review and comments, and our two research assistants, Josh Bauchner and Ian Zinn, who were invaluable.

Contributors: $\mathrm{HB}$ and JS contributed to all aspects of this project, including conception and design, data analysis, and writing of the paper. HB is the guarantor.

Funding: Institutional National Research Service Award and Faculty Development Program Grant to Department of Pediatrics, Boston University School of Medicine.

Competing interests: None declared.

1 Rennie D, Yank V. Disclosure to the reader of institutional review board approval and informed consent. JAMA 1997;277:922-3.

2 Olde Rikker MGM, ten Have HAMJ, Hoefnagels WHL. Informed consent in biomedical studies on aging: survey of four journals. $B M J$ 1996;313:1117.

3 Amdur RJ, Biddle C. Institutional review board approval and publication of human research results. JAMA 1997;277:909-14.

4 Institute of Medicine. Protecting data privacy in health services research. Washington, DC: National Academy Press, 2000.

5 Smith R. Informed consent: the intricacies. BMJ 1997;314:1059.

(Accepted 14 May 2001)

\section{Endpiece}

\section{Another Englishman}

As an Englishman [Kingsley Amis in Nashville], he was treated like an aristocratic curiosity: "We have another gentleman from Britain with us tonight," [said the chairman], displaying the modest pride of a provincial zoo official who reveals its possession of not one but two Arabian oryxes.

Martin Amis, Experience, London: Jonathan Cape, 2000 